Article

\title{
Brahmā at the Ajapāla Banyan Tree: Re-Examining Paintings at the Sulamani Temple, Bagan
}

\author{
Osmund Bopearachchi
}

Central and South Asian Art, Archaeology, and Numismatics, Group in Buddhist Studies, University of California, Berkeley, CA 94720-2230, USA; osmund@berkeley.edu

Received: 22 March 2020; Accepted: 3 April 2020; Published: 5 April 2020

\begin{abstract}
This article examines how the literary evidence corroborates with the visual evidence for the unusual presence of Brahmā with the Buddha at the Ajapāla banyan tree of the goatherd symbolizing the Fifth of the Seven Weeks after the Enlightenment of the Buddha in the paintings of the recessed chamber in the east corridor of the Sulamani temple in Bagan in Burma. The presence of Brahmā at the Ajapāla banyan tree is puzzling, because most of the mural paintings in Burma and Sri Lanka follow the chronological order given in the Nidannakathā, and, as a result, the intervention of Brahmā pleading with the Buddha to reconsider his decision not to expound the doctrine takes place in the Eighth Week. The painting of the encounter of Brahmā and the Buddha at the banyan tree in the Sulamani temple in the Fifth Week is thus a notable exception. It is argued that the visual artist of the Sulamani temple who introduced Brahmā in an earlier than normal context knew the narratives in the Pāli Mahāoagga and in the Nidānakathā well and, to shorten a long story, selected quite wisely the Ajapāla banyan tree of the goatherd where both events took place, meaning the Fifth and Eighth Weeks.
\end{abstract}

Keywords: Buddhism; enlightenment; Bagan; Sulamani temple

\section{Introduction}

The eighteenth-century murals in the principal image chamber of the Sulamani temple affords an illuminating case in the complex interaction among artists and sacred texts. The paintings depict the theme of the Seven Weeks that the Buddha spent in the vicinity of the Bodhi tree immediately after his great awakening ${ }^{1}$. At the end of these seven weeks, the deity named Sahampati, one of many brahmās in the Buddhist universe, finds the Buddha seated beneath the Ajapāla banyan tree, the site of the fifth week. Brahmā, seeing that the Buddha was inclined not to teach the Dharma, begged him to reconsider his decision ${ }^{2}$. In Buddhist art, this episode appears at the end of the seven-episode sequence. However, counter to the normal depiction of events at Bodh Gaya, the muralists at the Sulamani depicted the Buddha out of sequence, that is, when he appeared at the banyan tree of the goatherd during the Fifth Week. This unique example in Buddhist art reveals how artists at Bagan rose to the challenges of depicting narrative scenes.

1 This short article is based on the paper presented on 31 October 2019, at the workshop on the "Buddhist Art of Bagan", organized by the Department of Religious Studies of the Yale University. I have benefited largely from the discussions with friends and I wish to express my gratitude to Phyllis Granoff, Koichi Shionara, Donald Stadtner, Elizabeth Sharf, and Lilian Handlin. I am most thankful to Lilian Handlin for authorizing me to publish her photographs of the mural paintings of the Sulamani temple. The English translation of the Burmese captions written under the paintings under discussion were kindly provided to me by Than Zaw, and I also wish to express my gratitude to him.

2 Concerning the exhortation of the gods, see (Bays 1983, pp. 593-608; Hermann and Davids 1990, pp. 84-88; I, 5; Davids 1880, p. 206). 
The Sulamani temple was built in 1183, according to an inscription, and is a major landmark in Bagan. Like numerous temples during the Bagan period (ca. 11th-c. 13th centuries), patrons during the Konbaung period (1752-1885) commissioned murals that were placed over the earlier painted surfaces; these were rarely placed over the figures, but rather covered enormous areas that were merely covered with light colored washes at the time of the temple's original construction. The most spectacular later paintings at Pagan are found in the image chambers and corridors of the Sulamani. According to an inscription in the north entrance hall dated to 1779, the paintings of the Seven Weeks in the central eastern chamber belong to the late eighteenth century ${ }^{3}$. Today's entrance is on the western side but the recessed chamber with the paintings of the Seven Weeks was part of the main entrance of the shrine in the ancient period and probably also in the Konbaung era.

\section{First Seven Weeks after the Buddha's Enlightenment and the Inconsistencies in Texts}

Numerous versions of the events at Bodh Gaya are known, both within the Pali and Sanskrit traditions and even within the vernacular accounts of the Buddha's life. There are 'early' and 'late' descriptions of these key events but none can be taken as authoritative to the degree that numerous variations coexisted in time throughout South Asia, Sri Lanka, Southeast Asia, and the Far East. For example, according to the first Khandhaka of the Mahāvagga of the Vinaya Pitaka, the Buddha, after his enlightenment, fasted for only four weeks in the vicinity of the Bodhi tree ${ }^{4}$. The Chinese version of the Buddhacarita reduces the Seven Weeks to one ${ }^{5}$. However, the Mahāvastu, the Lalitavistara, and the Nidānakathā assert that the Blessed One fasted for seven weeks or forty-nine days ${ }^{6}$. Many of these differences have been discussed elsewhere ${ }^{7}$.

The Sanskrit, Pāli, and some Chinese texts relate that the Buddha spent the first seven days immediately after he had attained the perfect awakening, which marked his passage from Bodhisattvahood to Buddhahood, under the Bodhi tree. The texts differ, however, in subtle ways. For example, the Lalitavistara alone conveys two slightly different versions of the Buddha's First Week. At the beginning of Chapter XXII, it is simply stated that the Buddha sat at the foot of the Bodhi tree during the First Week ${ }^{8}$. But, in Chapter XXIV, once again referring to the First Week, it is said that the Blessed One gazed steadily at the 'king of the trees' (Bodhi tree) while seated with legs crossed ${ }^{9}$. In contrast, the Mahāvastu states that, when the Exalted One had awakened to the incomparable enlightenment, he sat for seven days on a bed of straw at the foot of the Bodhi tree with his legs $\operatorname{crossed}^{10}$. Notably, the Mahāvastu does not say that the Blessed One stared at the Bodhi tree with unblinking eyes while seated.

There is also a very clear disagreement concerning the Second Week between the two Sanskrit texts. It is now stated very clearly in the Mahāvastu that, having arisen from his Lion seat, for the extent of a period of seven days, the Exalted One kept on staring, while standing (note: not sitting), at the Bodhi tree with the stare of a serpent with an unblinking gaze ${ }^{11}$. Apart from the confusing information given for the First Week, the Lalitavistara has the Buddha spending the Second Week strolling throughout the region. According to the Mahāvastu, it was during the Third Week that the Buddha spent time walking up and down a long way in joy and ease. The confusion reached their apogee when the Lalitavistara

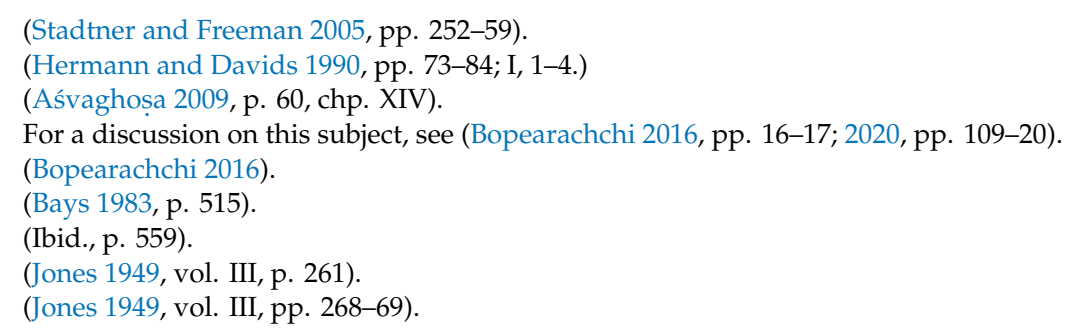


states the Buddha in the Third Week looked at the Bodhimanda (seat of enlightenment) without blinking his eyes ${ }^{12}$.

In two recent studies, we have attempted to demonstrate that in Gandhāran art, inspired largely by the Lalitavistara and the Mahāvastu, very few sculptures portray the events that took place during the Seven Weeks following his enlightenment when compared to the number of depictions of the other life events of the Buddha Gautama. The general paucity of images in Gandhāran art that depicts events in the Seven Weeks was likely a direct result of artists' difficulties in making visual sense of these two Sanskrit texts ${ }^{13}$.

Although there is general agreement between the Sanskrit Mahāvastu and the Pāli Nidānakathā about the first four weeks, there are notable differences regarding the fifth and the sixth weeks. According to the Mahāvastu, the Buddha spent the Fifth Week fasting in joy and ease at the abode of the Nāga king Mucilinda and in the Sixth Week the Blessed One went to the Shepherd's Nigrodha tree (another name for the goatherd's Ajapāla banyan tree) and sat there meditating on the Dharma. The Nidannakathā inverts the order of these two weeks and thus it was during the Sixth Week that Mucilinda protected the Buddha from the heavy rain and the Buddha spent the Fifth Week under the Shepherd's Nigrodha tree where Māra's daughters attempted to distract him ${ }^{14}$.

It is no exaggeration to say that the variations contained in these assorted Buddhist texts, when describing the Seven Weeks that the Buddha spent in the vicinity of the Bodhi tree, made it difficult for artists to depict. However, the exceptional appearance of Brahmā in the Fifth Week in the Sulamani paintings, instead of appearing after the Seven Weeks, was designed with full knowledge of the Pāli texts.

In a recent publication, we have discussed in detail the iconography of a relief depicting the Seven Weeks after the Buddha's enlightenment, most probably sculpted in Sri Lanka by an artist of the Nāgārjunakoṇda School using a hard lime slab from Andhra in India. It was found accidentally on the premises of the Rankirimada Rajamahā Vihāra in Kumbukwewa in Sri Lanka (Figure 1). As we have argued, the sequence of events depicted on the relief follows to the letter the narration in the Pāli Nidānakath $\bar{a}$, which was composed in the fifth century CE by Buddhaghoșa in Sri Lanka ${ }^{15}$. The Buddha is seated in samādhi in the center of the panel. In the middle register of the right frame, Māra is shown fleeing seated on the neck of his elephant Girimekhala. He looks back, with his head turned towards the victor. The attack of the demonic horde appears in the lower register immediately below the Buddha seated in samādhi. The rest of the scenes, corresponding to each week, are arranged counter-clockwise, starting from the register at the lower left-hand corner of the panel.

This register depicts the First Week, during which the Exalted One, having subdued the enemy, sat at the foot of the Bodhi tree enjoying the bliss of detachment. Next to the scene of the attack of Māra, the right frame of the lower register depicts the Second Week. The Buddha is seen standing and paying homage to the Bodhi tree with unblinking eyes. To the left of the frame is the fleeing Māra on the back of his elephant, while the Third Week, when Siddhārtha Gautama kept walking back and forth in the treasure-cloister, is depicted vertically. The top panel in the right-hand corner depicts the Blessed One seated in samädhi inside the jewelled house created by the gods, hence the Fourth Week. The missing frame at the top of the panel may have represented the Fifth Week when the Buddha spent seven days seated under the Ajapāla banyan tree. In the top panel of the left frame, the Nāga king Mucilinda with his seven hoods protects the Exalted One from the rain and thunder, hence this is the Sixth Week. The middle panel of the left vertical frame depicts the laymen, Trapusa, and Bhallika, two merchants from Orissa, offering a refreshment of honey to the Exalted One, hence this is the

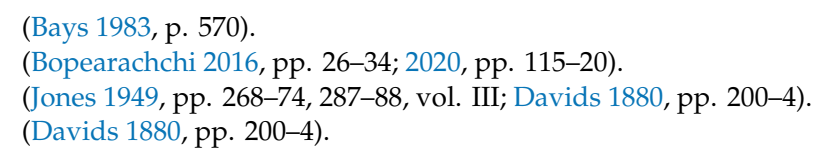


Seventh Week. When depicting the theme of the Seven Weeks following the Buddha's enlightenment, artists of the Kandyan period in Sri Lanka also follow the order given in the Nidannakath $\bar{a}^{16}$.

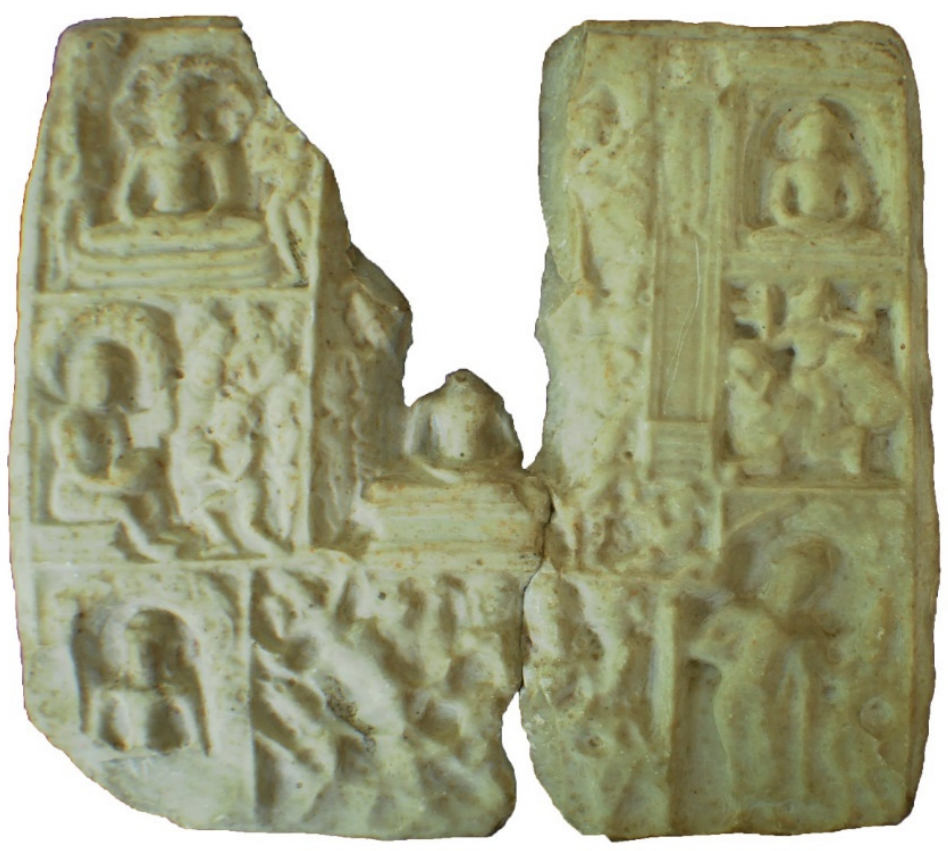

Figure 1. Relief depicting the Seven Weeks after the Buddha's enlightenment, Rankirimada Rajamahā Vihāra, Sri Lanka.

\section{The Seven Weeks as Depicted in the Sulamani Temple}

Several art historians have discussed paintings, terracotta plaques, and palm-leaf manuscripts depicting the Seven Weeks attested in Myanmar ${ }^{17}$. Contrary to the North Indian art schools, they have presumed that Myanmar (or Rāmañña, the Pāli name for Burma, or at least Lower Burma) artists follow the narrative of the Pāli Nidānakathā. Indeed, the famous sculptural scenes at the Ananda Temple at Bagan closely follow the Nidānakathā or at least later recensions that were true to the original ${ }^{18}$.

The paintings of the Seven Weeks at the Sulamani temple, apart from the first, have a caption under each depiction explaining the individual scenes. The enormous brick Buddha, restored and repainted many times, seated in bhümisparśamudrā in the deeply recessed chamber symbolizes the enlightenment and the First Week the Blessed One spent under the Bodhi tree (see Figure 2). It of course requires no explanatory caption but is taken to be the First Week. On either side of this large central image, the right and left walls bear the paintings of the other six weeks. The narration begins on the right wall, as the worshipper faces the central image. The sequence follows the Nidannakatha exactly, apart from the unusual placement of the Brahmā Sahampati. The captions are summations of the events recorded in the Nidannakathā. Reading from right to left, the Second Week is illustrated by the Buddha standing in three-quarter view in front of the Bodhimanda (see Figure 3). The caption beneath reads: "Staring with contemplation at the golden throne without blinking for seven days". As the caption underneath states: "Walking in deep contemplation in order to discard the misperception of celestial beings"; the next scene shows the Buddha walking along a cloistered path, thus evoking the Third Week (see Figure 4). Next, the Tathāgata is shown seated inside the jeweled house created by

\footnotetext{
6 See the discussion in (Bopearachchi 2016, pp. 48-63; 2020, vol. I, pp. 113-14, vol. II, pp. 325-26).

17 (Stadtner 1991; Bautze-Picron and Bautze 2003, pp. 39-43; Raymond 2010; Munier-Gaillard and Alexey 2017, pp. 48-50).

18 (Stadtner and Freeman 2005, p. 108).
} 
the gods. The depiction, of course, tallies with its caption: "Meditating in tranquility at the golden Yadanar Gara jewel house for seven days". This is thus the Fourth Week (see Figure 5).

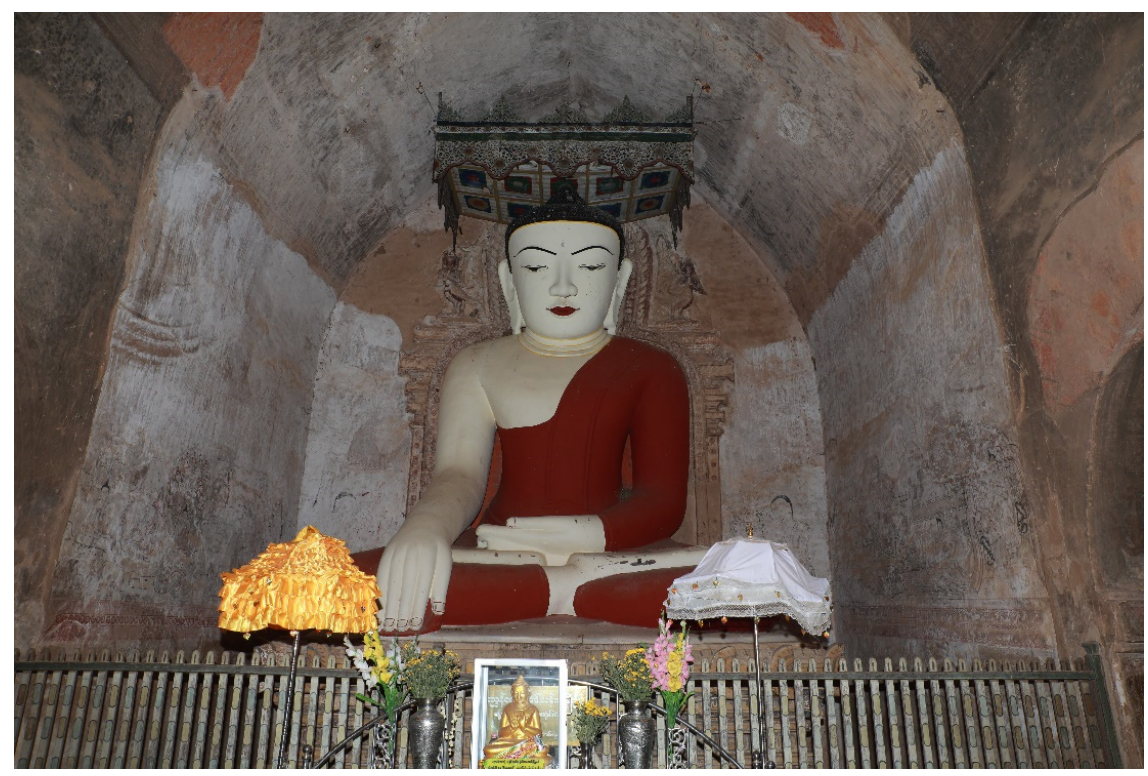

Figure 2. The Buddha seated in bhūmisparśamudrā, symbolizing the enlightenment and the first week, Sulamani temple, Bagan.

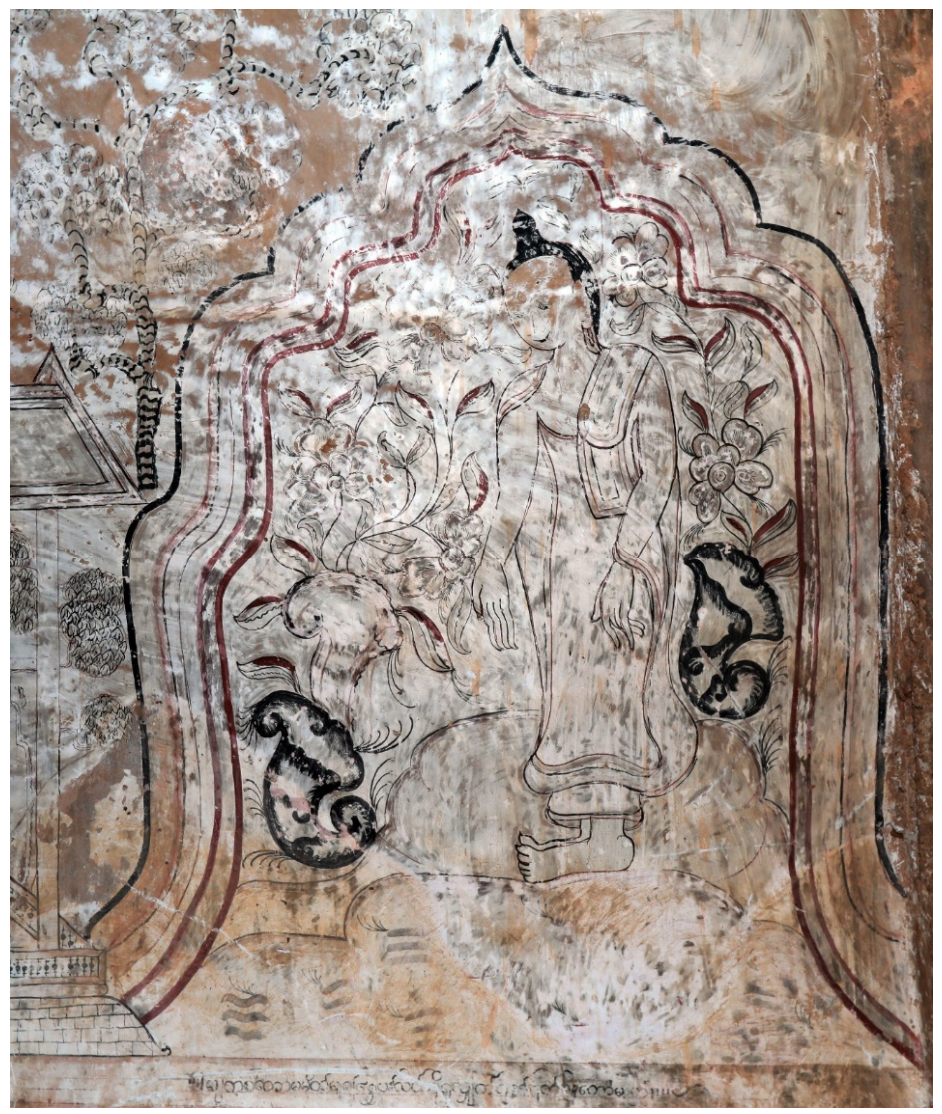

Figure 3. The Buddha standing in three-quarter view in front of the Bodhimanda, the Second Week, Sulamani temple, Bagan. 


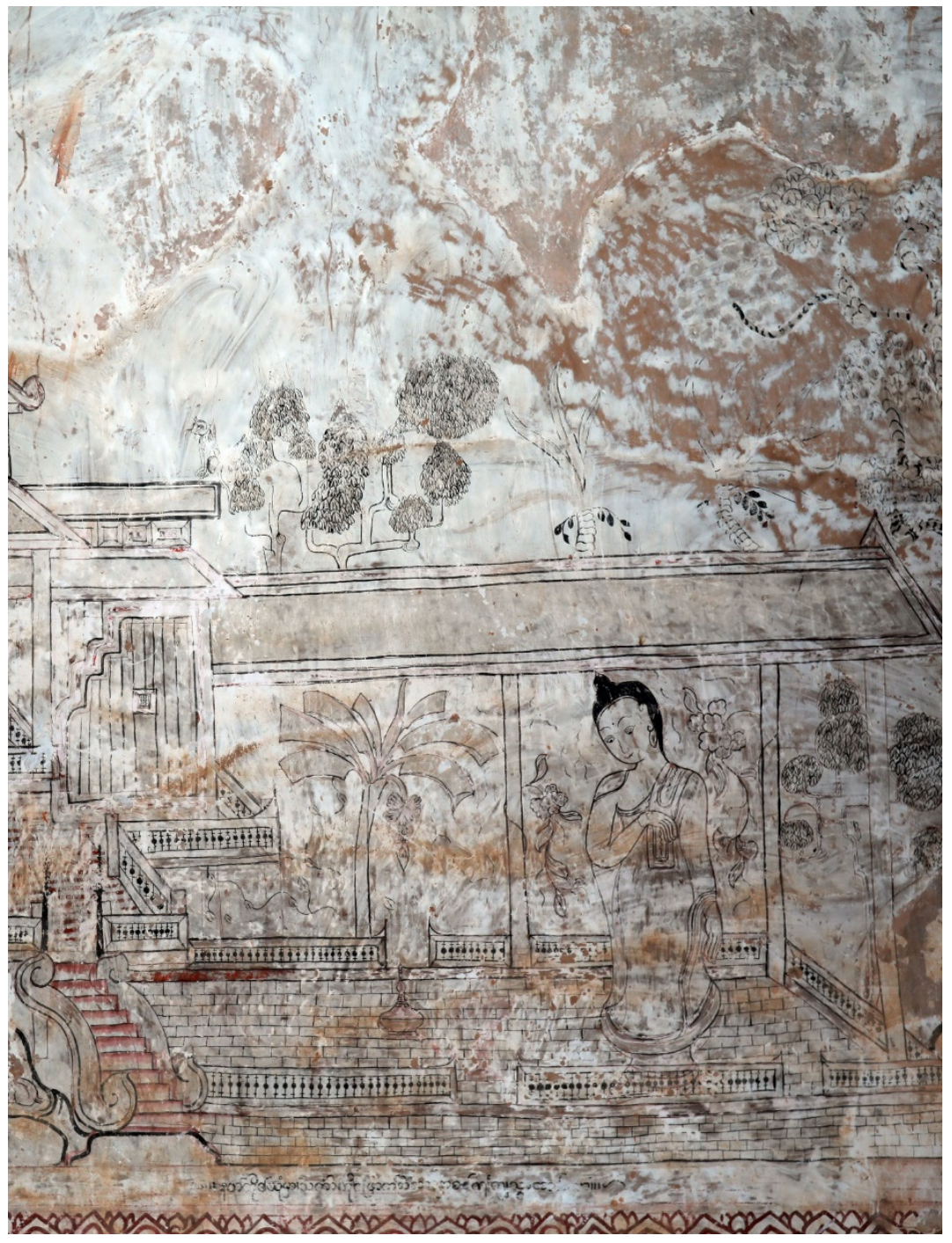

Figure 4. The Buddha walking along a cloistered path, the Third Week, Sulamani temple, Bagan. 


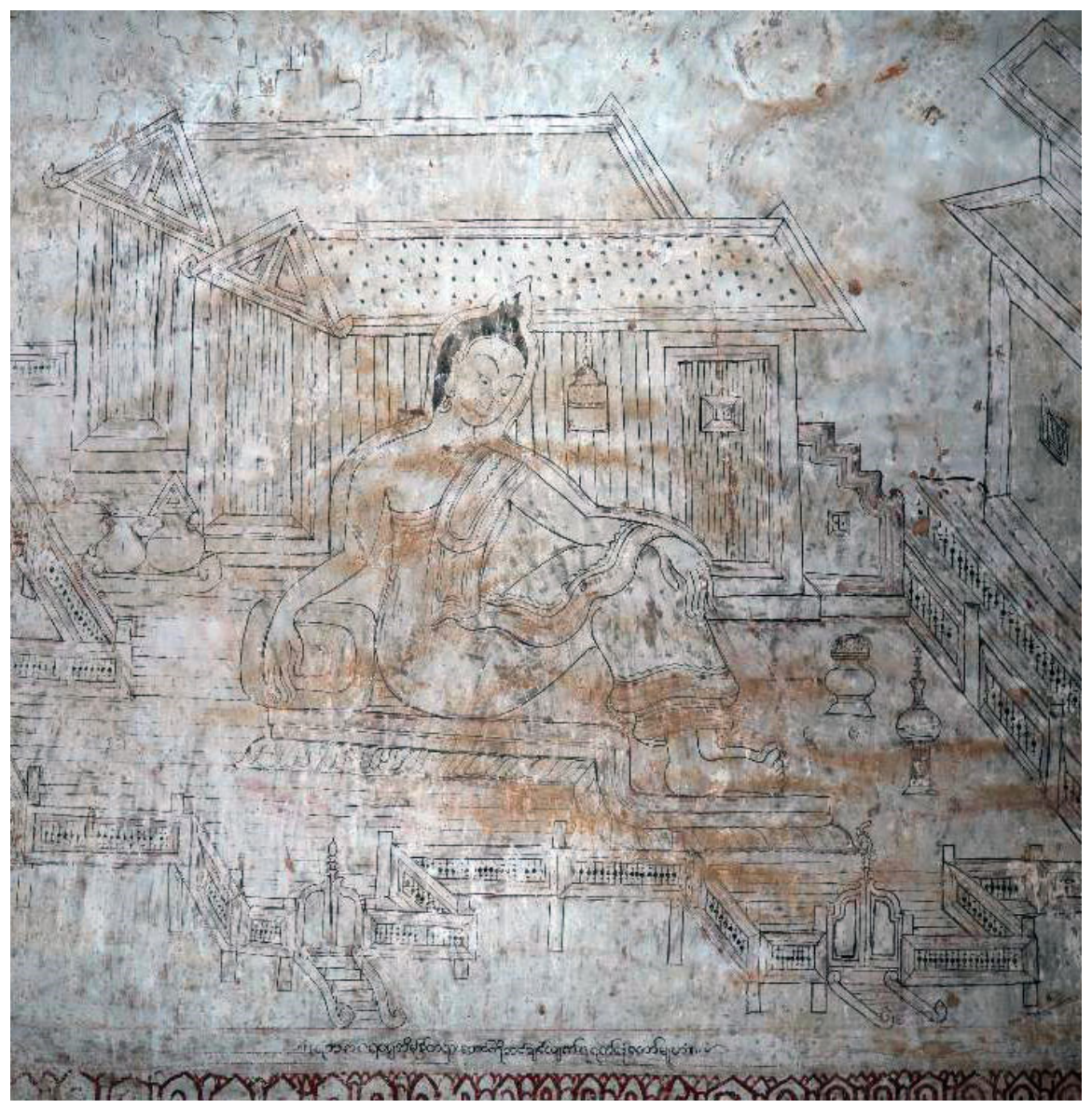

Figure 5. The Buddha seated inside the jeweled house created by the gods, the Fourth Week, Sulamani temple, Bagan.

In Pāli traditions, the Blessed One went during the Fifth Week to the Ajapāla Banyan tree of the goatherder (also called the Shepherd's Nigrodha tree) and sat under it meditating on the Dharma. This week is clearly depicted on the left wall (see Figure 6). Under the seated Buddha, goats are shown frolicking, identifying it as indeed the goatherd's banyan tree. It is noteworthy that the three daughters of Māra shown on some Burmese and Kandyan paintings for the Fifth Week are not depicted here ${ }^{19}$. Instead, Brahmā, identified in the Burmese inscription below as 'Thahanpati', appears to the left of the Blessed One. Before discussing the reasons for this exception, let us examine the final two weeks.

19 “When Craving (Taṇhā), Discontent (Arāti) and Lust (Rāgā), the three daughters of Māra, found their father sad and sorrowful and having heard the reason for his sorrow, they promised their father to subject the Buddha to their influence, and come back bringing him captive with them. But the Blessed One neither paid any attention to their words, nor raised his eyes to look at them. He sat, with mind free by the complete extinction of rebirth-conditions, enjoying the bliss of detachment. At the end, the three daughters were obliged accept their defeat again: saying 'Our father spoke the truth indeed. The saint, the Well-Farer of the world is not easily led away'. And so on, returned to their father". (Davids 1880, pp. 202-4). For the Burmese paintings depicting the three daughters of Māra, see (Stadtner 1991); and for the Kandyan paintings depictions the same event, see (Bopearachchi 2016, Figures 22, 26 and 28). 


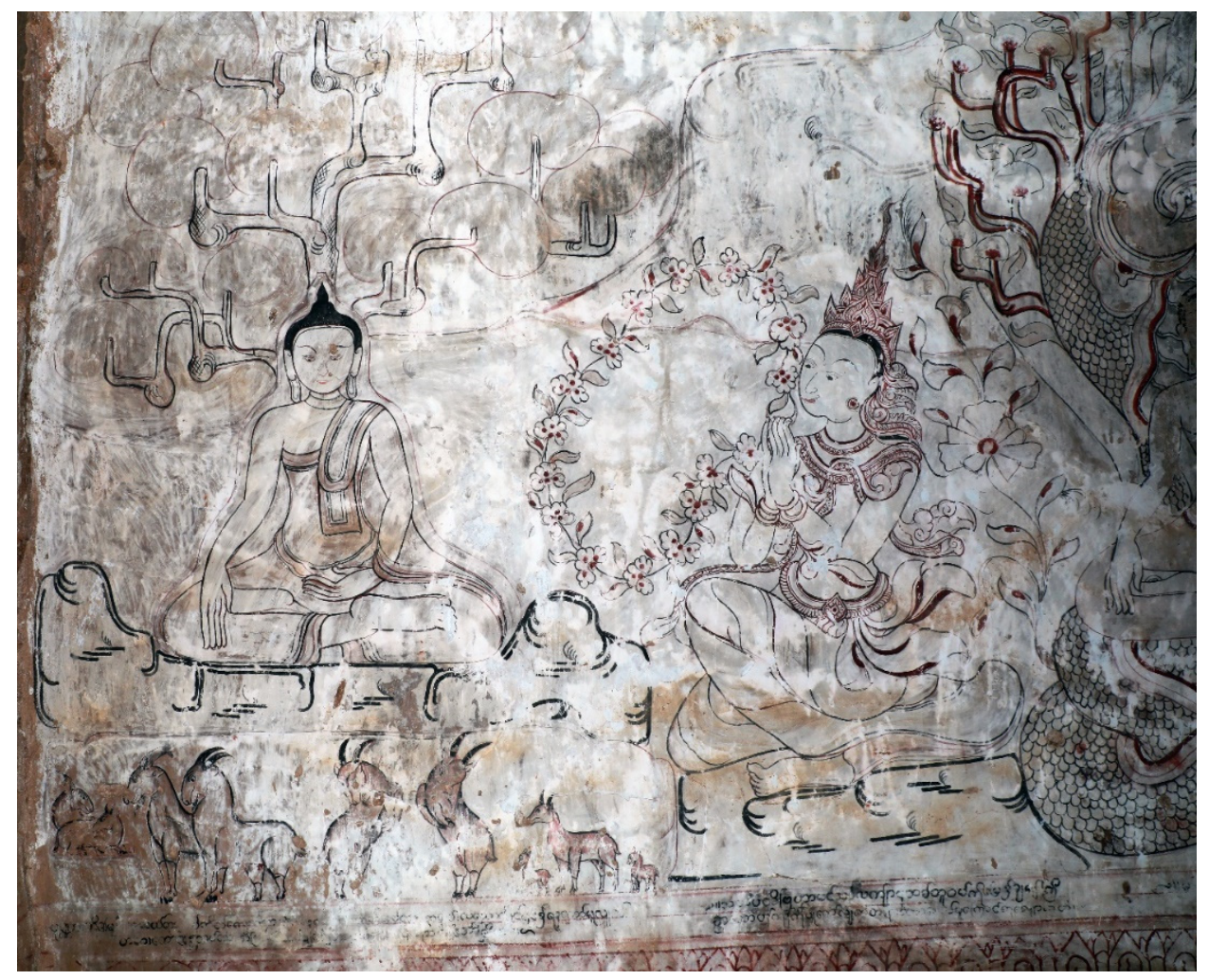

Figure 6. The Buddha under the Ajapāla Banyan tree of the goatherder, Brahmā to the left of the Blessed One, the Fifth Week. Sulamani temple, Bagan.

Mucilinda, the snake-king who protects the Buddha from a torrential downpour, was very popular in Southeast Asia, and the depiction of the snake-king in the painting of the Sixth Week at the Sulamani temple is exquisite (see Figure 7). It is not necessary to emphasize that, in this series of paintings, the episode of Mucilinda corresponds to the Sixth Week narrated in the Pāli Nidānakathā, but certainly not to the Fifth Week of the Sanskrit Mahāvastu. The Burmese caption beneath Mucilinda once again confirms this: "Sitting under the dragon's hood at the rim of Monchaleindar Lake for seven days". That a lake is mentioned, which is not part of the Nidānakatha and the Mahävagga, suggests that the Burmese painters were using a recension of the Nidannakatha $\bar{a}$. There is no mention of a lake in the extensive text accompanying the Burney parabaik-manuscript, ca. 1800, in the British Library, but the Burmese have depicted the seated Muchalinda in the middle of a lake ${ }^{20}$.

20 (Herbert 1992, p. 42); also see (Munier-Gaillard and Alexey 2017, p. 50). 


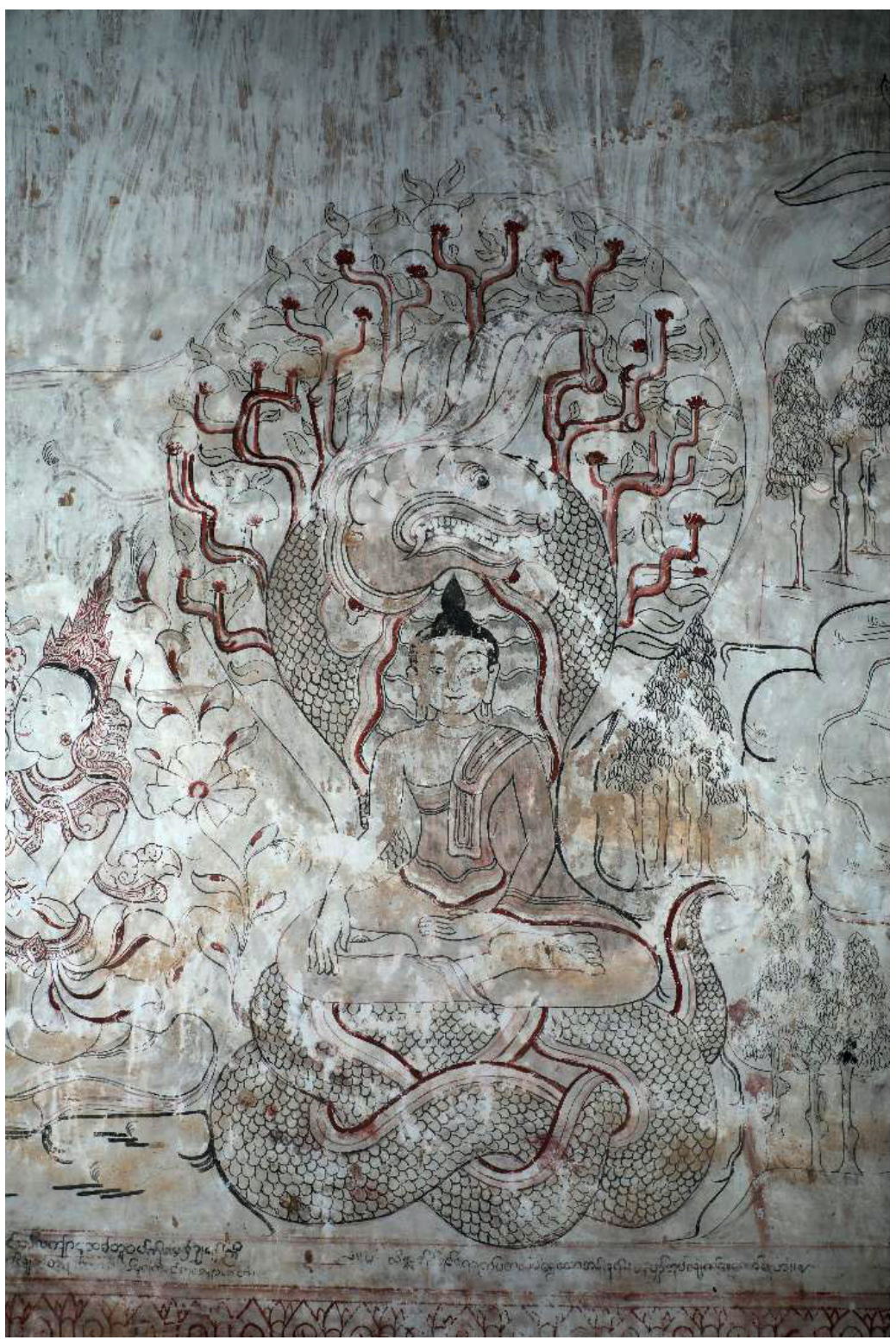

Figure 7. Mucilinda, the snake-king, protecting the Buddha from a torrential downpour, the Sixth Week, Sulamani temple, Bagan.

Finally, as in the Kandyan paintings, the end of the seven-week period is marked by the presence of Trapusa and Bhallika offering refreshments and the four World Guardians proffering alms bowls to the Blessed One ${ }^{21}$. In the same scene, we see the seated Buddha then eating the food offered by Trapusa and Bhallika (see Figure 8). If it were not for the exceptional appearance of Brahmā in the Fifth Week, the painting cycle in the Sulamani temple would follow to the letter the narration of the Nidānakathā. As we have mentioned earlier, seeing that the Buddha Gautama was not ready to turn the Wheel of the Dharma, Brahmā approached the Buddha several times together with Indra, the lord of the gods, and the gods of the Trayastrimśa Heaven and of many other realms begging him over and over again to teach. As evidenced by textual and visual depictions, this event takes place only in the Eighth Week. It is important to underline here that the Eighth Week is not depicted in the recessed chamber in the east corridor of the Sulamani temple. 


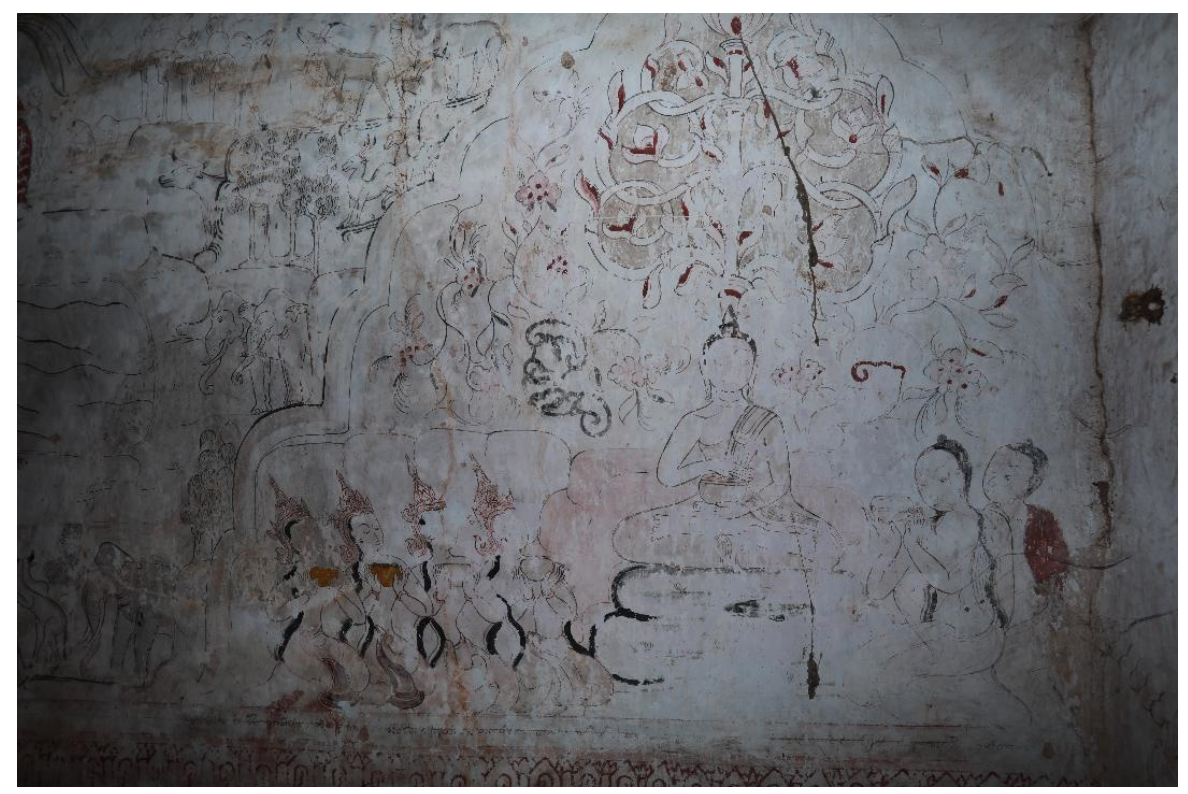

Figure 8. Trapuṣa and Bhallika offering refreshments and the four World Guardians offering alms bowls to the Blessed One, the Seventh Week, Sulamani temple, Bagan.

\section{Why Does the Sulamani Temple Include the God Brahmā in the Fifth Week?}

The presence of Brahmā during the Fifth Week in the mural painting of the Sulamani temple has no relationship with the Second Week described in the Chinese version of the Buddhacarita. Compressing the Seven Weeks into one, this text states: "The Buddha meditated seven days, and his mind was pure. He observed the bodhi tree, gazing without blinking" ${ }^{\prime 2}$. He then thought " ... about expounding the Law, and observed the strength of the afflictions of living beings" 23 . Then, Brahmā intervenes to persuade the Buddha to teach so as to rescue all suffering beings. "Brahmadeva knew what was on [the Buddha's] mind, [and understood] that he should be invited to turn the [wheel of the] Law. Releasing his pure light all around for the rescue of suffering beings, he came to see the worthy muni [enlightened one] and the signs of a great person who would expound the Law"24. The Buddha was pleased in his heart at Brahmā's invitation and expressed his intention to expound the Law ${ }^{25}$. Needless to say, the account in the Chinese version of the Buddhacarita does not correspond to the iconography of the Fifth Week in the mural painting cycle of the Seven Weeks at the Sulamani temple.

Since most of the mural paintings in Burma and Sri Lanka follow the chronological order given in the Nidannakathā, it may be worth pointing out that the intervention of Brahmā takes place immediately after the Seventh Week in the Pāli text and the mural painters of both countries faithfully respected this tradition. Why, then, in the Sulamani temple, does Brahmā's invitation take place in the Fifth Week? This confusion is also apparent in the Burmese captions beneath the painting of the Fifth Week. Strikingly, there are two captions under this scene, one under the Buddha, and the other under the figure of Brahmā. The partly illegible caption under the seated Buddha reads: "Being present underneath the Ijapala banyan tree...where the Brāhmana priest recites the magic ... " The caption under the god Brahmā reads: "Requested by Sahanpathi, the Brahmā king to deliver a sermon, offering the great festoon and putting his right knee on earth". If the depiction of Brahmā and the Burmese

\footnotetext{
Buddhacarita in praise of Buddha's Acts, chapter XIV, p. 60.

(Ibid, p. 63).

(Ibid, p. 64)

25 This narration in the Chinese version of the Buddhacarita is to be found on a rare Gandhāran sculpture depicting this event. The sculpture was in the National Museum of Kabul but was stolen when the museum was destroyed in May 1993 by rocket fire. The symbolism of the iconography of this exceptional sculpture is discussed in detail in (Bopearachchi 2020, vol. I, pp. 117-20; vol. II, no. 131, pp. 334-35).
} 
legend under it were removed, all the depictions of the Seven Weeks on the walls of the Sulamani temple would be found to follow to the letter in the narration in the Nidanakathā. It is evident that the second caption and the depiction of Brahmā holding the garland are out of the correct sequence. Why is Brahmā, who appears after the Seventh Week, shown in the setting of the Fifth Week?

A possible answer to this interpretation is to be found in the Nidanakathā and in the Mahāvagga of the Vinaya Pitaka. In its description of the events that took place immediately after the Seventh Week, the Nidānakathā states: "But the Perfectly Enlightened One rose up thence, and returned to the Shepherd's Nigrodha tree, and sat down at its foot. And no sooner was he seated there, considering the depth of the Doctrine which he had gained, than there arose in his mind a doubt (felt by each of the Buddhas as he became aware of his having arrived at the Doctrine) that he had not that kind of ability necessary to explain that Doctrine to others" ${ }^{\prime 26}$. It is at this moment that Brahmā intervenes. The important component in this description is that, during the Eighth Week, the Buddha returns to the Shepherd's Nigrodha tree where he spent the Fifth Week. For the artist who may have wished to make a long story short by placing Brahmā pleading with the Buddha to reconsider his decision at the same place is not that exceptional, because both events took place, in spite of the time gap, at the foot of the Ajapāla Banyan tree of the goatherd. Donald Stadtner argues that, "Holding a circular wreath, the artists wisely placed this delightful figure toward the front of the wall, near the Goatherder's Tree, out of chronological sequence, and labelled "Thahanpati" (Brahmā in Burmese)" 27. In other painted examples, both in murals and in manuscript illustrations, the appearance of Brahmā always comes at the conclusion of the seven-week period and is represented with his own separate Ajapāla tree, as we see in the Burney manuscript in which the return to the Ajapāla tree is specifically mentioned ${ }^{28}$.

The Mahāvagga reduces the Seven Weeks to four by omitting the Second, Third, and Fourth Weeks and jumping to the Fifth Week, as narrated in the Nidānakath $\bar{a}^{29}$. In other words, having spent the First Week under the Bodhi tree, the Buddha arose from the state of meditation, and went from the foot of the Bodhi tree to the goatherd's Ajapāla Banyan tree ${ }^{30}$. Here, the Mahāvagga narrates another event, which is not mentioned in the Nidānakathā; it is the dialogue between the Buddha and 'a certain Brāhmana' who asks the Blessed One: "By what, Gotama, does one become a Brāhmana, and what are the characteristics that make a man a Brāhmana?" The Buddha then answers his question. Although the Brāhmana is not depicted on the painting of the Fifth Week at the Sulamani temple, the caption below the seated Buddha alludes to him: "Being present underneath the Ijapala banyan tree ... where the Brāhmana priests recite the magic ... " This strongly suggests that the artist of the Sulamani temple knew about this event, which is found only in the Mahāvagga alone. Once we accept this working hypothesis, we can progress further and search for the reason behind this choice made by the painter. Having narrated the Sixth and Seventh Weeks, the Mahāvagga states that the Buddha, at the end of those seven days, arose from that state of meditation and went back to the Ajapāla Banyan tree ${ }^{31}$. Then, in the mind of the Buddha, who was alone and had retired into solitude, the following thought arose: "This doctrine will not be easy to understand to beings that are lost in lust and hatred". When the Lord Buddha pondered over this matter, his mind became inclined to remain in quiet, and not to preach the doctrine. The god Brahmā-referred to as 'Brahmā Sahampati' in the Mahāvagga-understood by the power of his mind the reflection that had arisen in the mind of the Buddha. Then, Brahmā adjusted his upper robe so as to cover one shoulder and, putting his right knee on the ground, raised

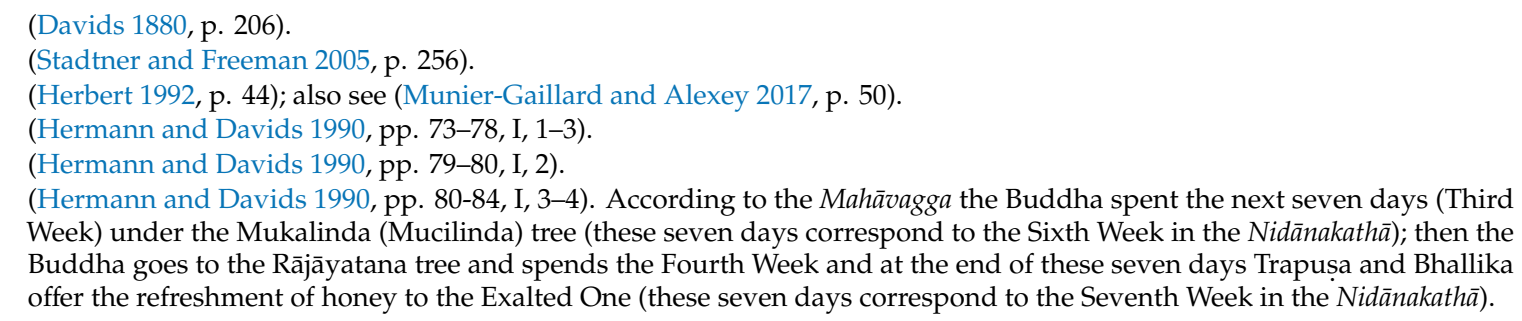
Week) under the Mukalinda (Mucilinda) tree (these seven days correspond to the Sixth Week in the Nidānakathā); then the Buddha goes to the Rājāyatana tree and spends the Fourth Week and at the end of these seven days Trapusa and Bhallika offer the refreshment of honey to the Exalted One (these seven days correspond to the Seventh Week in the Nidannakathā). 
his joined hands towards the Lord Buddha and said: "May the Lord Buddha preach the doctrine! May the Perfect One preach the doctrine! There are beings whose mental eyes are darkened by scarcely any dust; but if they do not hear the doctrine, they cannot attain salvation" (emphasis by the author). After a long dialogue, the Buddha heard Brahmā's solicitation, and gazed full of compassion on sentient beings all over the world with his (all-perceiving) eye. Then, Brahmā Sahampati understood: 'The Lord Buddha grants my request that he should preach the doctrine ${ }^{\prime 32}$.

This is exactly what the artist of the Sulamani temple has visualized in the scene of the Fifth Week. The Brahmā Sahampati, as he is also called in the Burmese caption, puts his right knee on the earth (ground) and invites the Buddha to preach. We are now certain that the visual Sulamani temple artists who introduced Brahmā in an earlier than normal context knew the two narratives in the Mahāvagga and in the Nidānakathā well; to abbreviate a long story, the artists quite cleverly conflated time and space and placed both episodes together in a single composition.

Funding: This research received no external funding.

Conflicts of Interest: The author declares no conflict of interest.

\section{References}

Aśvaghoṣa. 2009. Buddhacarita: In Praise of Buddha's Acts: (Taishō Volume 4, Number 192). BDK English Tripițaka Series; Berkeley: Numata Center for Buddhist Translation and Research.

Bautze-Picron, Claudine, and J. Bautze. 2003. The Buddhist Murals of Pagan: Timeless Vistas of the Cosmos. Toronto: Weatherhill.

Gwendolyn Bays, trans. 1983, The Voice of the Buddha, the Beauty of Compassion: The Lalitavistara Sutra (Tibetan Translation Series, vol. 1). Cazadero: Dharma Publishing.

Bopearachchi, Osmund. 2016. Seven Weeks after the Buddha's Enlightenmen: Contradictions in Text, Confusions in Art. Delhi: Manohar Publishers \& Distributors.

Bopearachchi, Osmund. 2020. When West Met East. Gandhāran Art Revisited. Delhi: Manohar Publishers \& Distributors. Davids, Rhys, ed. 1880. The Commentarial Introductions Entitled Nidāna-Kathā. The Story of the Lineage. Rhys Davids, trans. London: George Routledge and Sons Ltd.

Herbert, Patricia M. 1992. The Life of the Buddha. London: British Library.

Hermann, Oldenberg, and Rhys Davids. 1990. The Mahāvagga I-IV. In Vinaya Texts-Sacred Books of the East, Volumes XIII. Delhi: Motilal Banarsidass Publishers.

Jones, James. 1949. The Mahāvastu. Reprint 2007. London: The Pali Text Society.

Munier-Gaillard, Cristophe, and Kirichenko Alexey. 2017. La vie du Bouddha: Peintures murales de Haute-Birmanie. Findakly: Suilly-la-Tour.

Raymond, Catherine. 2010. The Seven Weeks: A 19th-century Burmese Palm-Leaf Manuscript. Journal of Burmese Studies 14: 255-67. [CrossRef]

Stadtner, Donald M. 1991. A Fifteen-Century Royal Monument in Burma and the Seven Stations in Buddhist Art. The Art Bulletin 73: 39-52. [CrossRef]

Stadtner, Donald Martin, and Michael Freeman. 2005. Ancient Pagan: Buddhist Plain of Merit. Bangkok: River Books.

(C) 2020 by the author. Licensee MDPI, Basel, Switzerland. This article is an open access article distributed under the terms and conditions of the Creative Commons Attribution (CC BY) license (http://creativecommons.org/licenses/by/4.0/). 